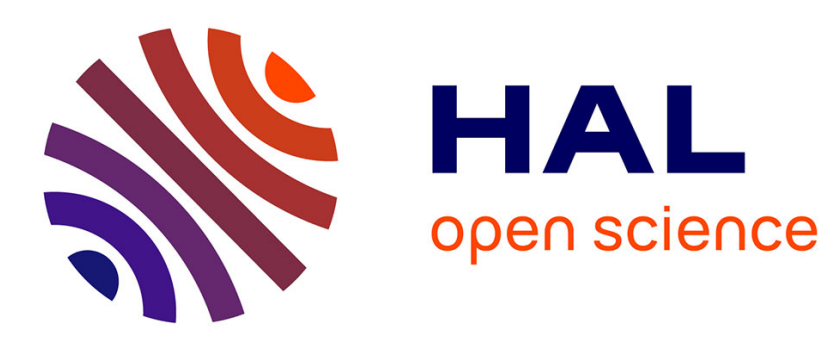

\title{
Associative olfactory learning of the red dwarf honey bee Apis florea
}

\author{
Roy Kaspi, Sharoni Shafir
}

\section{To cite this version:}

Roy Kaspi, Sharoni Shafir. Associative olfactory learning of the red dwarf honey bee Apis florea . Apidologie, 2012, 44 (1), pp.100-109. 10.1007/s13592-012-0160-y · hal-01201276

\section{HAL Id: hal-01201276 https://hal.science/hal-01201276}

Submitted on 17 Sep 2015

HAL is a multi-disciplinary open access archive for the deposit and dissemination of scientific research documents, whether they are published or not. The documents may come from teaching and research institutions in France or abroad, or from public or private research centers.
L'archive ouverte pluridisciplinaire HAL, est destinée au dépôt et à la diffusion de documents scientifiques de niveau recherche, publiés ou non, émanant des établissements d'enseignement et de recherche français ou étrangers, des laboratoires publics ou privés. 


\title{
Associative olfactory learning of the red dwarf honey bee Apis florea
}

\author{
Roy KASPI ${ }^{1,2}$, Sharoni SHAFIR ${ }^{1}$ \\ ${ }^{1}$ B. Triwaks Bee Research Center, Department of Entomology, Robert H. Smith Faculty of Agriculture, Food and \\ Environment, The Hebrew University of Jerusalem, 76100, Rehovot, Israel \\ ${ }^{2}$ The Israel Cohen Institute for Biological Control, Plant Production and Marketing Board, Citrus Division, P.O. \\ Box 235, Yahud-Monoson 56000, Israel
}

Received 22 December 2011 - Revised 17 June 2012 - Accepted 18 July 2012

\begin{abstract}
Apis florea has a wide distribution in southeast Asia, where it is the dominant honey bee species. It is an excellent colonizer, suggesting advanced behavioral plasticity. Using the proboscis extension response (PER) conditioning method, we investigated $A$. florea associative olfactory learning ability and compared it to the learning performances of Apis mellifera. A. florea workers reacted to pure odorant (conditioned stimulus) only when it was delivered in paired associations with sucrose rewards (unconditioned stimulus), and discriminated between a rewarded and unrewarded odor. Moreover, A. florea levels of acquisition in olfactory associative learning were higher in our study than those of $A$. mellifera, and they showed better retention of learning after $24 \mathrm{~h}$ than $A$. mellifera. Our results show that $A$. florea can be studied using PER procedures, enlarging the scope for future comparative studies of associative olfactory learning ability in bees.
\end{abstract}

\section{Apis mellifera / Hymenoptera / proboscis extension response / conditioning}

\section{INTRODUCTION}

It is well established that bees are highly responsive to resource (such as water, pollen, and nectar) stimuli and demonstrate high associative learning (olfactory, visual, and tactile) abilities (Menzel and Müller 1996; Giurfa and Sandoz 2012). The associative olfactory learning ability of the Western honey bee (Apis mellifera) has been widely studied using conditioning of the proboscis extension response (PER; also known as "proboscis extension reflex") under laboratory conditions (Takeda 1961; Bitterman et al. 1983; Bitterman 1996; Menzel and Müller 1996; Giurfa 2007). In PER conditioning, the measured response is whether or not a subject bee extends

Corresponding author: S. Shafir, shafir@agri.huji.ac.il

Manuscript editor: Monique Gauthier its proboscis to a conditioned stimulus (CS). The CS is presented to the subject followed by gently touching the bee antennae with sugar solution representing the unconditioned stimulus (US). If on a subsequent presentation of the CS, the bee responds with proboscis extension, it is interpreted as an indication of the bee having learnt the association.

The success of PER conditioning in advancing the study of learning and memory in $A$. mellifera has prompted attempts to use this technique for the comparative study of other bee species. Among the few species studied, the success of PER olfactory conditioning tends to increase with level of sociality and to be influenced by the foraging system (Mc Cabe and Farina 2010; Vorel and Pitts-Singer 2010). Solitary species have generally not been amenable to PER conditioning. For example, three species of megachilides (Osmia lignaria, 
Megachile rotundata, and Megachile pugnata) tested in classic PER conditioning procedure were found to not extend their proboscis to sugar stimulation (Vorel and Pitts-Singer 2010). The primitively eusocial Bombus terrestris and Bombus occidentalis showed mediocre to good performance (Laloi et al. 1999; Laloi and PhamDelegue 2004; Riddell and Mallon 2006; Riveros and Gronenberg 2009; Anfora et al. 2011), whereas eight other bumblebee species exhibited poorer performance (Vorel and PittsSinger 2010). Stingless bees comprise a large group of eusocial bees, which vary in foraging ecology, and their performance in PER conditioning ranges from poor: Scaptotrigona depilis (Mc Cabe et al. 2007), Tetragonisca angustula (Mc Cabe and Farina 2010), and Melipona scutellaris (Abramson et al. 1999; Roselino and Hrncir 2012); to mediocre: Trigona hockingsi (Frasnelli et al. 2011) and Melipona quadrifasciata (Mc Cabe et al. 2007; Mc Cabe and Farina 2009); to good: Trigona carbonaria and Austroplebeia australis (Frasnelli et al. 2011). The best performance is usually achieved by the eusocial $A$. mellifera. This is shown clearly in studies that compared honey bees and other species in a similar PER conditioning protocol (Mc Cabe et al. 2007; Vorel and PittsSinger 2010). Two species of eusocial Vespula wasps also achieved high performance (Vorel and Pitts-Singer 2010).

Contrary to the trend of a correlation between PER conditioning performance and sociality, however, Anfora et al. (2010) recently found very good PER conditioning in the solitary bee Osmia cornuta. Vorel and Pitts-Singer (2010) were not able to elicit PER in O. lignaria. Thus, there are differences in performance even between species in the same genus. Furthermore, there are differences in PER conditioning between subspecies (Abramson et al. 1997) and castes (Shafir et al. 2005) of A. mellifera. Interestingly, despite the great amount of research on PER conditioning in A. mellifera, we are not aware of any studies of PER conditioning in other Apis species.

The red dwarf honey bee (Apis florea) is an open-nesting dwarf honey bee native to Southern Asia where it is the dominant honey bee species (Oldroyd and Wongsiri 2006). Like all Apis species it is eusocial. Five years ago, the first $A$. florea nests were discovered in the Red Sea port cities of Aqaba, Jordan, and Eilat, Israel, and it has since established itself there (Moritz et al. 2010). A. florea is a very successful colonizer, even where conditions are less than favorable for this tropical bee, including sub-tropical and semi-arid areas (Hepburn et al. 2005). For example, an introduced $A$. florea nest was detected in Sudan in 1985 (Lord and Nagi 1987) and it has since established and coexisted with the native $A$. mellifera sudanensis honey bees (El Shafie et al. 2002).

Its highly colonizing abilities suggest that it is capable of adapting its nesting behavior and foraging strategies to new habitats (e.g., Mogga and Ruttner 1988), and suggest that it has a good learning ability. Various chemicals were found to repel and affect the foraging behavior of $A$. florea workers under laboratory (Gupta 1987c, 1988, 1989b), semi-field (Gupta 1987a; Mishra and Sihag 2009a; Naik et al. 2010), and field (Gupta 1987b; Mishra and Sihag 2009b) conditions. Moreover, Gupta (1986, 1989a) showed habituation of $A$. florea workers to some of these chemicals. We hypothesized that A. florea associative olfactory learning ability could be investigated using the PER conditioning method. The goals of the present study were (a) to determine whether $A$. florea workers could be studied using standard PER conditioning procedures, (b) to investigate their associative olfactory learning ability and (c) to compare their levels of acquisition and retention in olfactory associative learning with those of $A$. mellifera.

\section{MATERIALS AND METHODS}

\subsection{Insects}

A. florea workers (ca. 2,000 workers of various ages, from a single nest) were collected from the vicinity of the city of Eilat. They were placed in two cages with ad libitum "candy" made of honey and sucrose powder mix $(1: 2, w / w)$ as a food source. The 
bees were kept at a cool temperature inside an icebox, and transferred to a cold room $\left(18 \pm 1{ }^{\circ} \mathrm{C}\right)$ within $48 \mathrm{~h}$ of collection. A. mellifera bees (ca. 1,000 workers of various ages, from a single hive) were collected from our standard honey bee hives (at the apiary of the B. Triwaks Bee Research Center, Rehovot), placed in a cage with ad libitum access to "candy", and kept in a cold room $\left(18 \pm 1{ }^{\circ} \mathrm{C}\right)$. For both species, cages were plastic containers $(18 \times 18 \times 12 \mathrm{~cm})$ with a screened top. Bees were kept in the cold room for not more than 27 days before testing.

\subsection{Stimuli}

Odors were delivered to the bees from a $1-\mathrm{ml}$ glass syringe (BD, Glaspak Tuberculin, Mexico) and mounted on a training station. We placed $3.5 \mu \mathrm{l}$ of pure odors, geranyl acetate (98 \%, Aldrich, USA) or 1-octanol (99\%, Sigma, USA), on a strip of filter paper $(2.5 \pm 0.5 \times 50 \mathrm{~mm}$, Whatman ${ }^{\circledR}$ ) inside the glass syringe. One tip of the glass syringe was placed $1.5 \mathrm{~cm}$ from the bees' head, and the other was attached via silicon tubing to a computer controlled valve and air pump, which created an air flow of $13 \mathrm{~cm}^{3} / \mathrm{s}$. Thus, in every trial the bee experienced a mechanosensory stimulus of the air flow, but in conjunction with a particular odor.

An exhaust stream was formed by a 9-cmdiameter tube that was placed $13 \mathrm{~cm}$ behind the bee and connected to a vent.

\subsection{Procedure}

A. mellifera workers were harnessed as in Shafir et al. (1999; 2008). Bees were transferred into glass vials and were anesthetized by brief exposure to low temperature $\left(-4{ }^{\circ} \mathrm{C}\right)$ in a freezer until their movement was halted. Bees were then strapped into sectioned hollow plastic tubes by a 2-mm-wide strip of tape that was wrapped around the tube and the dorsal thorax of the bee. A. florea workers were harnessed within the narrow end of a sectioned plastic tube. The tube was $5 \mathrm{~mm}$ in diameter, but its sectioned end could be tightened to $2-3 \mathrm{~mm}$ diameter. A small plastic ring (3 $\mathrm{mm}$ in diameter, $2-3 \mathrm{~mm}$ wide) was slid over the bee and the sectioned plastic tube, so that the ring would wrap the tube tightly around the bee's thorax,

Figure 1. Harnessed A. florea workers are conditioned using sucrose solution (US; $40 \% w / w$ ) as a reward.

leaving only its head and forelegs free (Figure 1). In addition, they were strapped by a 2-mm-wide strip of tape that held the ring in place. The bees' abdomen was not covered.

One hour later, bees were fed for $3 \mathrm{~s}$ with sucrose solution $40 \%(w / w)$; their antennae were tapped with a cotton wool stick that was saturated with sucrose solution and they were allowed to feed freely for $3 \mathrm{~s}$. The US was a $40 \%(w / w)$ sucrose solution in all experiments. One hour later, motivation tests were performed; each bee's antennae were gently tapped with a drop of sucrose solution (bees were not allowed to feed) and only those that extended their proboscis were selected. Then we set up the selected bees on experimental rulers (see below), and started the PER experiments 15 min later. The number of bees that passed the motivation test was recorded. Harnessing and training of bees were done in a temperature controlled room at $27 \pm 1{ }^{\circ} \mathrm{C}$.

Conditioning trials were repeated with new bees on successive days within 27 days of bee collection. Up to 24 harnessed bees were lined up on two rulers, at 4-cm intervals, with partitions between the bees. In order to familiarize the bees with the training station stimulations, they were introduced one by one to the training station $5 \mathrm{~s}$ before each conditioning trial. After each trial, the ruler was slid until the next bee was in position. In all experiments, the time between rewarded trials was $8 \mathrm{~min}$. 


\subsection{Experiment 1: paired and unpaired associations with sucrose rewards}

A. florea workers were subjected to paired or unpaired associations with sucrose rewards (i.e., the US) and their PER were recorded. In the paired group, six conditioning trials were performed, in which the bees were exposed to odor stimulus for $7 \mathrm{~s}$. During the first $4 \mathrm{~s}$, the PER was recorded. Then, during the next $3 \mathrm{~s}$, the sucrose reward was presented to the bees. Each conditioning phase with all the bees took up to $4 \mathrm{~min}$ (intertrial interval, ITI $=4 \mathrm{~min}$ ), and was followed by a similar phase with blank trials (ITI $=4 \mathrm{~min}$ ) where bees were positioned on the training station but were not subjected to any stimulus (CS or US). So the time between rewarded trials was $8 \mathrm{~min}$. Similarly, 12 pseudo-conditioning trials were performed in the unpaired group, 6 CS-only trials during the first 4 min followed by US-only trials (ITI= $4 \mathrm{~min}$; time between rewarded trials $=8 \mathrm{~min}$ ). In the CS-only trials, only odor was provided for $7 \mathrm{~s}$ and any PER during the first $4 \mathrm{~s}$ were recorded. Throughout the US-only trials, odor was not provided, yet sucrose rewards were presented for $3 \mathrm{~s}$.

\subsection{Experiment 2: A. florea discrimination between a rewarded and unrewarded odor}

We tested the ability of $A$. florea to distinguish between a positively rewarded odor (A, i.e., $\mathrm{CS}+$ ) and an unrewarded odor (B, i.e., CS-). Two odors, geranyl acetate and 1-octanol, were used alternately as A and $\mathrm{B}$ on different testing days. Each odor was kept in a separate glass syringe. Odor B was delivered for $7 \mathrm{~s}$ with no US. In contrast, odor A was delivered for $7 \mathrm{~s}$, and $4 \mathrm{~s}$ after the onset of the odor (CS) delivery the US was presented to the trained bee. We performed 12 trials with each bee, with an ITI of 8 min (regardless of whether the trial was rewarded or not). The sequences of the conditioning trials were: ABBABAABABBA.

\subsection{Experiment 3: acquisition and retention in olfactory associative learning of $\boldsymbol{A}$. florea and $\boldsymbol{A}$. mellifera}

We compared the learning ability and retention of A. florea with those of A. mellifera. We performed six trials with each bee, with an ITI of 8 min. Geranyl acetate (CS) was delivered for $7 \mathrm{~s}$, and $4 \mathrm{~s}$ later, the US was presented to the bee for $3 \mathrm{~s}$. After the trials ended, the bees were kept harnessed in the training room and allowed to feed freely on candy. The next day, $22 \mathrm{~h}$ after the end of conditioning trials the candy was removed. Two hours later, a retention test was performed just like the conditioning trials above, but without feeding. After $8 \mathrm{~min}$, the test was repeated with 1-octanol as CS.

\subsection{Data analyses}

In each experiment, we summed the number of PER obtained throughout the CS presentations for each individual bee. We compared the scores of different groups with the Mann-Whitney $U$ test. We compared discrimination between a rewarded and unrewarded odor of the same individuals with a Wilcoxon signed-rank test. We used Fishers' exact test (Zar 1999) to compare between the percentage of A. florea and A. mellifera workers that passed the motivation tests. We compared the percentage of cumulated initial responses (i.e., the number of bees that responded for the first time to the CS during the trials) between $A$. florea and A. mellifera workers by Kaplan-Meier survival analyses (both by Log-rank (weights later events) and by Wilcoxon (weights early events) tests) with censored data. Bees that did not respond to the CS in all six trials were treated as censored observations. We compared retention of olfactory associative learning between the two species of bees by Chi-square test. Statistical analyses were performed using SigmaStat, version 3.5 (SPSS Inc., Chicago, IL) or JMP, version 7 (SAS Institute, Cary, NC).

\section{RESULTS}

\subsection{Experiment 1: paired and unpaired associations with sucrose rewards}

A total of 152 A. florea workers were initially harnessed, $59.2 \%$ of them responded to sucrose solutions and passed the motivation tests. The PER proportions of $A$. florea workers that were subjected to paired $(n=40)$ and unpaired $(n=37)$ 


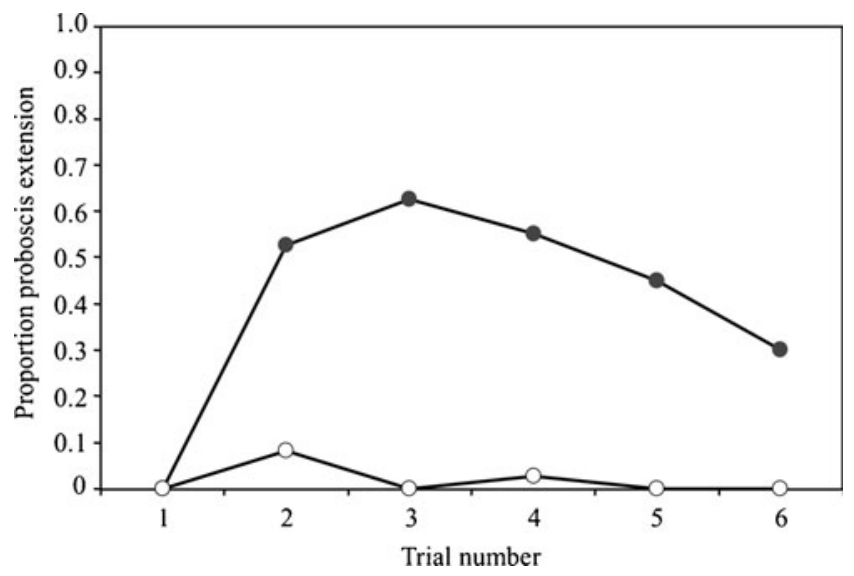

Figure 2. The proportion of $A$. florea workers that performed proboscis extension responses during paired $(n=$ 40; full circle) and unpaired ( $n=37$; empty circle) conditioning trials. Proportion responses between the two treatments differed significantly (Mann-Whitney $U$ test: $U=1,302, P<0.001$ ).

presentations of CS and US were significantly different (Mann-Whitney $U$ test: $U=1,302$, $P<0.001)$. A. florea workers reacted to pure odor (CS) only when it was presented in paired associations with sucrose rewards (US). In the paired group, by the third conditioning trail, $62.5 \%$ of the bees performed PER. In contrast, when CS was presented in unpaired associations with US, the bees showed a negligible PER (Figure 2).

\subsection{Experiment 2: A. florea discrimination between a rewarded and unrewarded odor}

In this experiment a total of $151 \mathrm{~A}$. florea workers were initially harnessed, $74.8 \%$ of them passed the motivation tests. The bees significantly discriminated between a rewarded and unrewarded odor (Figure 3; Wilcoxon signed rank test: $Z=-7.909, n=91, P<0.001$ ). The response to 1-octanol was greater than that to geranyl acetate (Mann-Whitney $U$ test: $U=$ $730.5, P=0.036)$ when these odors were used as CS+ (i.e., the rewarded odor). In contrast, the bees showed negligible PER in the unrewarded trials, regardless of the odor used as CS- (i.e., the unrewarded odor) (Mann-Whitney $U$ test: $U=976.5, P=0.951)$.

\subsection{Experiment 3: acquisition and retention in olfactory associative learning of $A$. florea and $A$. mellifera}

A total of $235 \mathrm{~A}$. florea and 229 A. mellifera workers were initially harnessed. The two species differed in the percentage of bees that passed the motivation tests (A. florea: $54.9 \%$; A. mellifera: $68.6 \%$; Fisher's exact test: $P=0.003$ ). Acquisition in both species showed asymptotic responses that were peaked by the third conditioning trial (Figure 4a); decline in PER proportions in later trials probably reflects the influence of satiation. However, the level of acquisition in A. florea ( $n=$ $112)$ was higher than that of A. mellifera $(n=131)$; the total number of responses of $A$. florea bees was greater than that of $A$. mellifera bees (MannWhitney $U$ test: $U=5,647, P=0.002$ ). Moreover, A. florea rate of acquisition was faster than that of A. mellifera; from the second trial onwards, the cumulative percentage of subjects that responded at least once was consistently greater for $A$. florea than for $A$. mellifera (Log-rank test: $\chi^{2}=21.9, d f=$ $1, P<0.001$; Wilcoxon test: $\chi^{2}=24.4, d f=1, P<$ 0.001 ; Figure 5). More A. mellifera (38.2 \%) than A. florea $(16.1 \%)$ bees never responded to the CS in all six trials (Fisher's exact test: $P=0.0002$ ) and were censored from this analysis. 


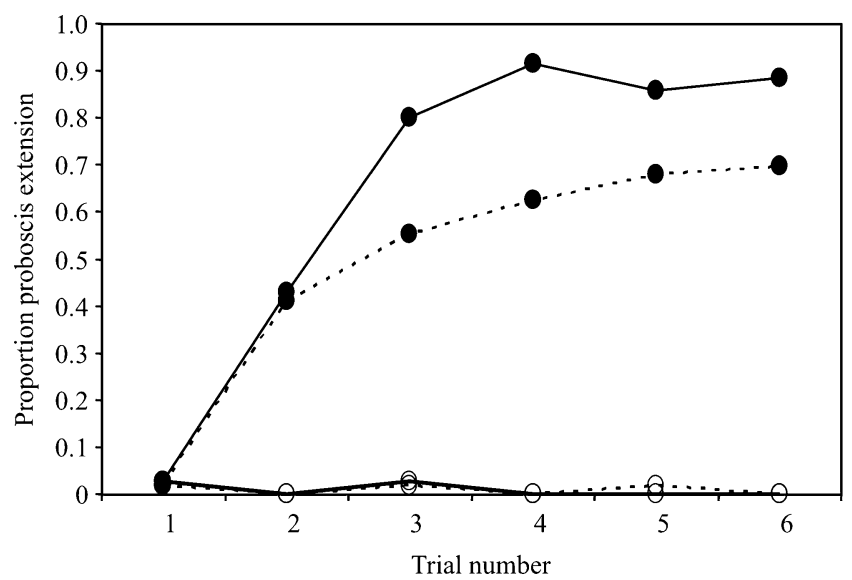

Figure 3. The proportion of $A$. florea workers $(n=91)$ that performed proboscis extension responses in a discrimination task between rewarded (full circle) and unrewarded (empty circle) odors [geranyl acetate (dotted line) or 1-octanol (solid line)]. The bees significantly discriminated between a rewarded and unrewarded odor (Wilcoxon signed-rank test: $Z=-7.909, n=91, P<0.001$ ). The response to 1 -octanol was greater than that to geranyl acetate when these odors were the rewarded odors (Mann-Whitney $U$ test: $U=730.5, P=0.036$ ).

Twenty-four hours after the end of conditioning trials, we performed a retention test. Fewer A. florea $(69.0 \%)$ than A. mellifera $(88.3 \%)$ bees survived this period (Likelihood ratio $\left.\chi^{2}=12.6, d f=1, P=0.004\right)$, possibly due to the size difference between the species. Twelve A. florea and two A. mellifera bees did not respond to the unconditioned stimulus during both retention test trials, and were excluded from further analyses. A. florea level of retention in olfactory associative learning was significantly greater than that of A. mellifera. Percent response to the conditioned odor, geranyl acetate, was $86.0 \%(n=57)$ for $A$.

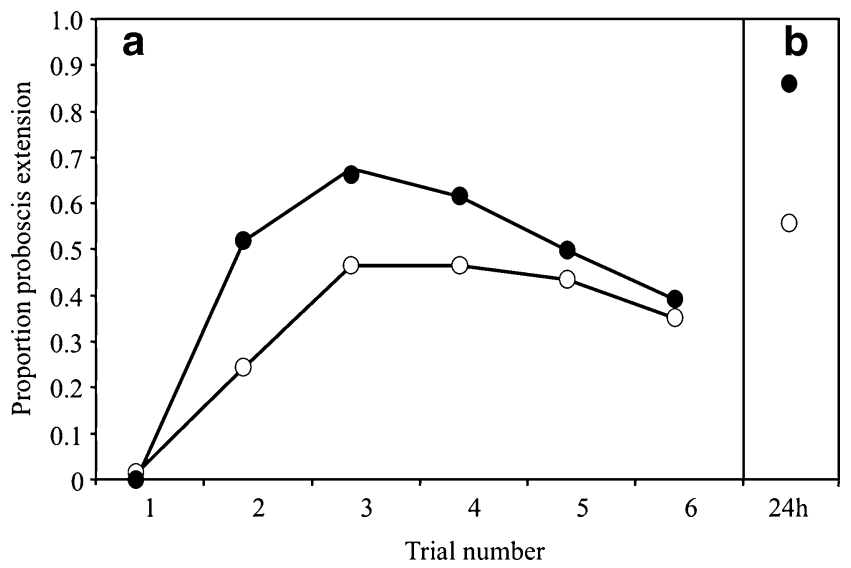

Figure 4. The proportion of $A$. florea (full circle) and A. mellifera (empty circle) workers that performed proboscis extension responses during conditioning trials (a), and in a retention test to the conditioned odor, geranyl acetate, after $24 \mathrm{~h}(\mathbf{b})$. The total number of responses of A. florea was greater than that of A. mellifera both during conditioning $\left(n_{\text {A. florea }}=112, n_{\text {A. mellifera }}=131\right.$; Mann-Whitney $U$ test: $\left.U=5,647, P=0.002\right)$ and in the retention test $\left(n_{\text {A. florea }}=57 ; n_{\text {A. mellifera }}=104\right.$; Likelihood ratio $\left.\chi 2=16.4, d f=1, P<0.0001\right)$. 


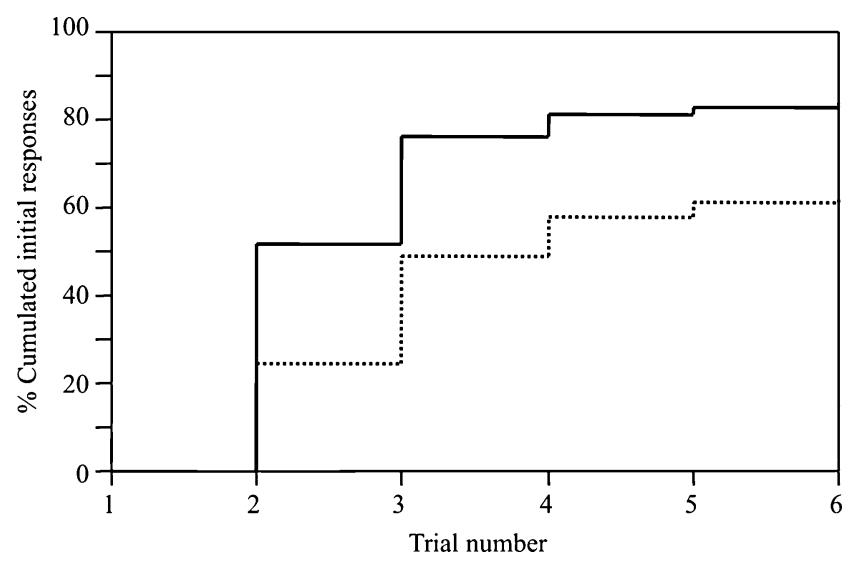

Figure 5. Cumulated percentages of initial proboscis extension responses of $A$. florea (solid line) and $A$. mellifera (dotted line) workers during conditioning trials. The cumulative percentage was consistently greater for A. florea than for A. mellifera $\left(n_{A}\right.$. florea $=112, n_{\text {A. mellifera }}=131$; Wilcoxon test: $\left.\chi^{2}=24.4, d f=1, P<0.001\right)$.

florea workers and $55.8 \%(n=104)$ for $A$. mellifera workers (likelihood ratio $\chi^{2}=16.4, d f$ $=1, P<0.0001$; Figure 4b). The specificity of the retention is evident in both species in comparison to the low level of response in the test that followed with a novel odor, 1-octanol. Percent response was $14.0 \%$ for $A$. florea and $9.6 \%$ for $A$. mellifera (likelihood ratio $\chi^{2}=$ $0.71, d f=1, P=0.40)$.

We conducted an additional analysis to control for a potential selection bias due to mortality of bees between the two phases of the experiment. Since acquisition peaked at trial 3 (Figure 4a) and most bees that responded to the CS had responded by that trial (Figure 5), we compared the retention of only those bees that had responded in trial 3. As before, A. florea level of retention was significantly greater than that of $A$. mellifera. $90.5 \%(n=42)$ of the A. florea workers performed PER to the conditioned odor, compared with $60.4 \%(n=53)$ of $A$. mellifera workers (likelihood ratio $\chi^{2}=11.9, d f=1, P=0.0006$ ).

\section{DISCUSSION}

We have shown that $A$. florea workers are amenable to conditioning of the proboscis extension response. A. mellifera consistently performs very well in PER conditioning and can therefore be used as a standard for comparison with other species. During the motivation test, 55 and $69 \%$ of harnessed A. florea and A. mellifera workers, respectively, extended their proboscis upon stimulation of their antennae with sugar solution. Such behavior is not observed in all bees studied. For example, Vorel and Pitts-Singer (2010) failed to elicit PER in three megachilid bees tested, even after maintaining the bees in less restrictive harnesses and for prolonged times, which may facilitate PER. Such modifications are often necessary in order to elicit PER in bumblebees, but even then response proportions are lower than those typically found in A. mellifera. Within bumblebees, B. terrestris (Laloi et al. 1999; Laloi and Pham-Delegue 2004; Riddell and Mallon 2006; Anfora et al. 2011) and $B$. occidentalis (Riveros and Gronenberg 2009) seem most amenable to PER and limited success has been reported for another eight species studied (Vorel and Pitts-Singer 2010). Bombus impatiens is a common species in the eastern USA, and is grown commercially for pollination, yet we are not aware of reports of successful elicitation of PER in this species. In preliminary attempts at harnessing $B$. impatiens workers, the bees remained restless, buzzing continuously, and did not elicit PER (unpublished data).

Differences between species in eliciting PER reflect distinct temperament and behavior, asso- 
ciated with the harnessing technique, which do not necessarily relate to learning abilities. Freeflying bumblebees, for example, including $B$. impatiens, perform very well in olfactory (Cnaani et al. 2006) and visual (Macuda et al. 2001; Wiegmann et al. 2003; Burns and Thomson 2006) conditioning tasks.

We found that in addition to being amenable to being harnessed and eliciting the PER, A. florea workers also performed well in an olfactory conditioning task. A group that was presented with an odor in association with a sugar reward quickly learned to respond to the odor, whereas a group that was presented with an odor that was not in association with a sugar reward did not respond to this odor (experiment 1). Furthermore, in a discrimination task, subjects could readily discriminate between an odor associated with reward and an odor not associated with reward (experiment 2). Being amenable to PER conditioning procedure does not necessarily guarantee good performance in learning and discrimination tasks. For example, in a comparison between $A$. mellifera drones and workers, Shafir et al. (2005) found that drones generally responded more with PER (unpublished data), but that workers showed better discrimination and greater sensitivity to reward variability. Also, workers tested in spring were more responsive than those tested in winter, but their sensitivity to reward variability was similar (Shafir et al. 1999).

The good learning performance of $A$. florea in our study is consistent with the generally good performance of social bees in various cognitive tasks. Performance tends to be better in social vs. solitary bees, though the differences may depend on bee size and ecology and on the particular task tested (Dukas and Real 1991; Perez and Waddington 1996; AmayaMarquez and Wells 2008).

Several factors may have contributed to the faster learning and better retention of A. florea relative to $A$. mellifera. In an olfactory associative learning task, performance could be affected by differences in sensory physiology or the salience of the particular odors that we tested. However, the chemoreceptors on the antennae of $A$. florea are similar to those of $A$. mellifera (Gupta 1992).
Differences in PER are also influenced by sensitivity to sucrose (Scheiner et al. 2004) and by energetic state (Ben-Shahar and Robinson 2001; Mayack and Naug 2011). Differences in size and metabolic rate may have influenced workers of the two species differently. In our experiment, harnessed $A$. mellifera workers had a higher feeding motivation than harnessed $A$. florea workers (68.6\% vs $54.9 \%$ ), which may have affected their performance in PER experiments. To further compare cognitive performance, future studies would need to standardize gustatory sensitivity (Scheiner et al. 2005), test cognitive performance in additional modalities, and to control for motivational state. Since $A$. florea and A. mellifera are phylogenetically distant within Apis, our findings suggest that PER conditioning may be an appropriate tool for comparative studies between all honey bee species.

\section{ACKNOWLEDGMENTS}

We thank Dorit Avni, Nadav Ezra, and Yael Garbian for their helpful advice and assistance and Tatty Klass for technical assistance. Special thanks to Haim Kalev for his invaluable assistance. This research was supported by grant no. 824-0116-10 of the Chief Scientist Office, Ministry of Agriculture and Rural Development, Israel.

Apprentissage olfactif associatif de l'abeille naine, Apis florea

Apis mellifera / Hymenoptera / réponse d'extension du proboscis / conditionnement

Assoziatives olfaktorisches Lernen bei der Zwerghonigbiene Apis florea

Apis mellifera / Hymenoptera / Rüsselreflex / Konditionierung

\section{REFERENCES}

Abramson, C.I., Aquino, I.S., Silva, M.C., Price, J.M. (1997) Learning in the Africanized honey bee: Apis mellifera L. Physiol Behav 62(3), 657-674 
Abramson, C.I., Aquino, I.S., Stone, S.M. (1999) Failure to find proboscis conditioning in one-day old africanized honey bees (Apis mellifera L.) and in adult arucu honey bees (Melipona scutellaris). Int $\mathrm{J}$ Comp Psychol 12(4), 242-262

Amaya-Marquez, M., Wells, H. (2008) Social complexity and learning foraging tasks in bees. Caldasia 30(2), 469-477

Anfora, G., Frasnelli, E., Maccagnani, B., Rogers, L.J., Vallortigara, G. (2010) Behavioural and electrophysiological lateralization in a social (Apis mellifera) but not in a non-social (Osmia cornuta) species of bee. Behav Brain Res 206(2), 236-239

Anfora, G., Rigosi, E., Frasnelli, E., Ruga, V., Trona, F., Vallortigara, G. (2011) Lateralization in the invertebrate brain: left-right asymmetry of olfaction in bumble bee, Bombus terrestris. PLoS ONE 6(4)

Ben-Shahar, Y., Robinson, G.E. (2001) Satiation differentially affects performance in a learning assay by nurse and forager honey bees. J Comp Physiol ASens Neural Behav Physiol 187(11), 891-899

Bitterman, M.E. (1996) Comparative analysis of learning in honeybees. Anim Learn Behav 24(2), 123-141

Bitterman, M.E., Menzel, R., Fietz, A., Schafer, S. (1983) Classical conditioning of the proboscis extension in honeybees (Apis mellifera). J Comp Psychol 97(2), 107-119

Burns, J.G., Thomson, J.D. (2006) A test of spatial memory and movement patterns of bumblebees at multiple spatial and temporal scales. Behav Ecol 17(1), 48-55

Cnaani, J., Thomson, J.D., Papaj, D.R. (2006) Flower choice and learning in foraging bumblebees: effects of variation in nectar volume and concentration. Ethology 112(3), 278-285

Dukas, R., Real, L.A. (1991) Learning foraging tasks by bees: a comparison between social and solitary species. Anim Behav 42, 269-276

El Shafie, H.A.F., Mogga, J.B.B., Basedow, T. (2002) Studies on the possible competition for pollen between the honey bee, Apis mellifera sudanensis, and the imported dwarf honey bee Apis florea (Hym., Apidae) in North-Khartoum (Sudan). J Appl Entomol-Z Angew Entomol 126(10), 557-562

Frasnelli, E., Vallortigara, G., Rogers, L.J. (2011) Origins of brain asymmetry: lateralization of odour memory recall in primitive Australian stingless bees. Behav Brain Res 224(1), 121-127

Giurfa, M. (2007) Behavioral and neural analysis of associative learning in the honeybee: a taste from the magic well. J Comp Physiol A -Neuroethol Sens Neural Behav Physiol 193(8), 801-824

Giurfa, M., Sandoz, J.C. (2012) Invertebrate learning and memory: fifty years of olfactory conditioning of the proboscis extension response in honeybees. Learn Mem 19(2), 54-66

Gupta, M. (1986) Conditioning of Apis florea F. as a function of duration of exposure to chemical vapours at Rc50 and Rc60 dilutions. Beitr Ent Berlin 36(2), S225-S229
Gupta, M. (1987a) Behaviour of Apis florea F. to some ketones and essential oils under semi-field conditions. Indian Bee J 49, 29-32

Gupta, M. (1987b) Efficacy of ketones on the foraging behavior of Apis florea F. in field conditions. Apidologie 18(2), 121-128

Gupta, M. (1987c) Olfactory response of Apis florea $\mathrm{F}$ to some essential oils. J Apic Res 26(1), 3-10

Gupta, M. (1988) Olfactory response of Apis florea $\mathrm{F}$ to some phenolic ketones. Comp Physiol Ecol 13(2), 64-68

Gupta, M. (1989a) Conditioning of Apis florea worker bees as a function of exposure to chemical vapors at $0.05 \%$ concentration. Zool Jahrb Abt Allg. Zool Physiol Tiere 93(2), 215-218

Gupta, M. (1989b) Olfactometric evaluation of the response of Apis florea $\mathrm{F}$. to some repellent ketones. Zool Jahrb Abt Allg Zool Physiol Tiere 93(1), 97104

Gupta, M. (1992) Scanning electron-microscopic studies of antennal sensilla of adult worker Apis florea F. (Hymenoptera, Apidae). Apidologie 23(1), 47-56

Hepburn, H.R., Radloff, S.E., Otis, G.W., Fuchs, S., Verma, L.R., Ken, T., Chaiyawong, T., Tahmasebi, G., Ebadi, R., Wongsiri, S. (2005) Apis florea: morphometrics, classification and biogeography. Apidologie 36(3), 359-376

Laloi, D., Pham-Delegue, M.H. (2004) Bumble bees show asymmetrical discrimination between two odors in a classical conditioning procedure. J Insect Behav 17(3), 385-396

Laloi, D., Sandoz, J.C., Picard-Nizou, A.L., Marchesi, A., Pouvreau, A., Taser, J.N., Poppy, G., PhamDelegue, M.H. (1999) Olfactory conditioning of the proboscis extension in bumble bees. Entomol Exp Appl 90, 123-129

Lord, W.G., Nagi, S.K. (1987) Apis florea discovered in Africa. Bee World 68(1), 39-40

Macuda, T., Gegear, R.J., Laverty, T.M., Timney, B. (2001) Behavioural assessment of visual acuity in bumblebees (Bombus impatiens). J Exp Biol 204(3), 559-564

Mayack, C., Naug, D. (2011) A changing but not an absolute energy budget dictates risk-sensitive behaviour in the honeybee. Anim Behav 82(3), 595-600

Mc Cabe, S.I., Farina, W.M. (2009) Odor information transfer in the stingless bee Melipona quadrifasciata: effect of in-hive experiences on classical conditioning of proboscis extension. J Comp. Physiol A -Neuroethol Sens Neural Behav Physiol 195(2), 113-122

Mc Cabe, S.I., Farina, W.M. (2010) Olfactory learning in the stingless bee Tetragonisca angustula (Hymenoptera, Apidae, Meliponini). J Comp Physiol A -Neuroethol Sens Neural Behav Physiol 196(7), 481-490

Mc Cabe, S.I., Hartfelder, K., Santana, W.C., Farina, W.M. (2007) Odor discrimination in classical con- 
ditioning of proboscis extension in two stingless bee species in comparison to Africanized honeybees. J Comp Physiol A -Neuroethol Sens Neural Behav Physiol 193(11), 1089-1099

Menzel, R., Müller, U. (1996) Learning and memory in honeybees: from behavior to neural substrates. Annu Rev Neurosci 19, 379-404

Mishra, S., Sihag, R.C. (2009a) Efficacy of some chemicals as repellents against two honey bee species, Apis mellifera L. and Apis florea F. in semi-field trials. J Apic Sci 53(1), 53-66

Mishra, S., Sihag, R.C. (2009b) Efficacy of some repellent chemicals against two honey bee species, Apis mellifera L. and Apis florea $\mathrm{F}$. in field trials. J Apic Sci 53(2), 21-29

Mogga, J., Ruttner, F. (1988) Apis florea in Africasource of the founder population. Bee World 69(3), 100-103

Moritz, R.F.A., Haddad, N., Bataieneh, A., Shalmon, B., Hefetz, A. (2010) Invasion of the dwarf honeybee Apis florea into the near East. Biol Invasions 12(5), 1093-1099

Naik, D.G., Puntambekar, H., Anantpure, P. (2010) Essential oil of Terminalia chebula fruits as a repellent for the Indian honeybee Apis florea. Chemistry \& Biodiversity 7(5), 1303-1310

Oldroyd, B.P., Wongsiri, S. (2006) Asian honey bees. Harvard University Press, Cambridge

Perez, S.M., Waddington, K.D. (1996) Carpenter bee (Xylocopa micans) risk indifference and a review of nectarivore risk-sensitivity studies. Am Zool 36(4), 435-446

Riddell, C.E., Mallon, E.B. (2006) Insect psychoneuroimmunology: immune response reduces learning in protein starved bumblebees (Bombus terrestris). Brain Behav Immun 20(2), 135-138
Riveros, A.J., Gronenberg, W. (2009) Olfactory learning and memory in the bumblebee Bombus occidentalis. Naturwiss 96(7), 851-856

Roselino, A.C., Hrncir, M. (2012) Repeated unrewarded scent exposure influences the food choice of stingless bee foragers, Melipona scutellaris. Anim Behav 83(3), 755-762

Scheiner, R., Page, R.E., Erber, J. (2004) Sucrose responsiveness and behavioral plasticity in honey bees (Apis mellifera). Apidologie 35(2), 133-142

Scheiner, R., Kuritz-Kaiser, A., Menzel, R., Erber, J. (2005) Sensory responsiveness and the effects of equal subjective rewards on tactile learning and memory of honeybees. Learn Mem 12(6), 626-635

Shafir, S., Wiegmann, D.D., Smith, B.H., Real, L.A. (1999) Risk-sensitive foraging: choice behaviour of honeybees in response to variability in volume of reward. Anim Behav 57, 1055-1061

Shafir, S., Menda, G., Smith, B.H. (2005) Caste-specific differences in risk sensitivity in honeybees, Apis mellifera. Anim Behav 69, 859-868

Shafir, S., Reich, T., Tsur, E., Erev, I., Lotem, A. (2008) Perceptual accuracy and conflicting effects of certainty on risk-taking behaviour. Nature 453(7197), 917-920

Takeda, K. (1961) Classical conditioned response in the honey bee. J Insect Physiol 6(3), 168-179

Vorel, C.A., Pitts-Singer, T.L. (2010) The proboscis extension reflex not elicited in Megachilid bees. $\mathrm{J}$ Kans Entomol Soc 83(1), 80-83

Wiegmann, D.D., Wiegmann, D.A., Waldron, F.A. (2003) Effects of a reward downshift on the consummatory behavior and flower choices of bumblebee foragers. Physiol Behav 79(4-5), 561-566

Zar, J.H. (1999) Biostatistical analysis. Prentice Hall, Upper Saddle River, New Jersey 